\title{
Artykuty
}

Klio. Czasopismo poświęcone dziejom Polski i powszechnym

PL ISSN 1643-8191, t. 24 (1)/2013, s. 75-98

(c) (1) $\ominus$ DOI: $10.12775 / \mathrm{KLIO} .2013 .004$

\section{RAdOSEAW BugOWSKI}

(Toruń)

\section{Kariera braci Cierpiatkowskich, właścicieli „Pomorskiej Fabryki Samochodów, Motorów i Maszyn" (w międzywojennym Toruniu)"}

\begin{abstract}
Tednym z popularnych nurtów badawczych, cieszącym się powodzeniem w obszarze historii społecznej, jest badanie losów zawodowych i karier społecznych poszczególnych osób i rodzin, które wiąże się z poszukiwaniem oraz próbami odkrywania mechanizmów decydujących o ich pozycji majątkowej i statusie społecznym. Są to zagadnienia ściśle związane ze studiami prozopograficznymi, prowadzonymi głównie przez badaczy epok wcześniejszych niż ta, w ramach której mieszczą się przedstawione tu wyniki badań.

Zadaniem artykułu jest wpisanie się $\mathrm{w}$ ten nurt $\mathrm{w}$ odniesieniu do dwudziestowiecznej, toruńskiej rodziny Cierpiałkowskich. Poniższe badania ukazują losy zawodowe braci, Pawła i Konstantego Cierpiałkowskich, na tle przemian społecznych i gospodarczych w międzywojennym Toruniu, a będących konsekwencją rozwoju motoryzacji.
\end{abstract}

* Projekt został sfinansowany ze środków Narodowego Centrum Nauki przyznanych na podstawie decyzji numer DEC-2011/03/N/HS3/04064. 
Do początków lat 20. XX wieku o rodzinie Cierpiałkowskich w Toruniu słyszeli nieliczni. Pierwsza adresowa wzmianka pojawiła się w księdze adresowej z 1897 r., odnotowującej J. Cierpiałkowskiego, murarza mieszkającego na Mokrem przy ul. Kozackiej $9^{1}$. Kolejna informacja pojawiła się w spisie mieszkańców z 1908 r. Odnotowany został wówczas Antoni Cierpiałkowski, z zawodu robotnik, zamieszkały na Podgórzu przy ul. Schlüsselmühle 29². W 1912 r. w Toruniu mieszkał Bruno Cierpiałkowski, z zawodu manewrowy ${ }^{3}$, na Podgórzu zaś - wspomniany Antoni ${ }^{4}$.

Nazwisko stało się rozpoznawalne na początku lat 20. za sprawą Pawła i Konstantego Cierpiałkowskich, synów Johanna Cierpiałkowskiego i jego żony Marianny, z domu Tuszyńskiej, którzy w latach 80. XIX w. zamieszkali na Mokrem. W 1890 r. urodził się tam młodszy ze wspomnianych braci, Konstanty5. Paweł zaś, jako najstarsze dziecko w wielodzietnej rodzinie, urodził się zapewne kilka lat wcześniej, zanim rodzina przybyła na Mokre. W 1888 r. urodziła się ich siostra Cecylia, w styczniu 1893 r. dwaj bracia - Bolesław i Johann', w 1895 r. siostra Apolonia ${ }^{7}$, a w 1897 r. urodził się brat Walenty ${ }^{8}$. Wszyscy zostali ochrzczeni w parafii pw. Najświętszej Marii Panny.

${ }^{1}$ Adreß-Buch der Stadt Thorn, Podgórz u. Mocker sowie des Landkreises Thorn für das Jahr 1897, hrsg. von P. Kirsten und W. Jaskulski, Thorn 1897, s. 151.

${ }^{2}$ Adressbuch für Thorn Stadt und Land 1908, Thorn 1908, cz. B, s. 1. W wydanej w 1904 r. w Toruniu Adressbuch nebst Allgemeinen Geschäftsanzeiger von Stadt und Landkreis Thorn auf das Jahr 1904. Mit einem Plan von Thorn und Umgebund nie odnajdujemy wzmianki o rodzinie Cierpiałkowskich. Nie odnajdujemy jej również w starszym wydaniu księgi adresowej: Adreß-Buch der Stadt Thorn und deren Vorstädte für das Jahr 1900, bearb. von P. Stüwe, Thorn 1900.

3 Adressbuch für Thorn Stadt und Land 1912, Thorn 1912, s. 16.

${ }^{4}$ Ibidem, cz. B, s. 1. Warto dodać, że mieszkańcem Podgórza był również Jan Cierpiałkowski, z zawodu robotnik, zamieszkały przy Rynku 71a, zob.: ibidem.

${ }^{5}$ Archiwum Akt Dawnych Diecezji Toruńskiej [dalej: ADT], Parafia pw. Wniebowzięcia Najświętszej Marii Panny [dalej: Parafia pw. NMP], Liber baptisatorum 1887-1898, sygn. AA010, s. 248-249.

6 Ibidem, s. 482.

7 Ibidem, s. 688-689.

${ }^{8}$ Ibidem, s. 832-833. 
Po wejściu w wiek dorosły i usamodzielnieniu się, kariera Pawła i Konstantego rozwijała się dynamicznie na początku lat 20. XX w. Wtedy to Paweł i Konstanty wspólnie prowadzili firmę zarejestrowaną pod nazwą „Auto-Centrala Bracia Cierpiałkowscy”, oferującą usługi naprawcze dla samochodów osobowych i ciężarowych, usługi wulkanizacyjne oraz skup i sprzedaż pojazdów9 ${ }^{9}$ Siedziba firmy, której właściciele pierwsze kroki w branży stawiali przy reperowaniu samochodów dla armii gen. Józefa Hallera $^{10}$, mieściła się w Toruniu przy ul. Podmurnej 6/8 ${ }^{11}$. Wiosną $1921 \mathrm{r}$. Auto-Centrala rozszerzyła swoją działalność o prowadzenie koncesjonowanej przez państwo szkoły szoferskiej ${ }^{12}$.

W styczniu 1922 r. bracia Cierpiałkowscy przejęli fabrykę maszyn „Kuhl i Klein” zlokalizowaną przy Szosie Chełmińskiej 33 i oficjalnie poinformowali, że będą ją nadal prowadzić pod handlową nazwą „Bracia Cierpiałkowscy Pomorska Fabryka Samochodów, Motorów i Maszyn"13. W rzeczywistości, poza szumną nazwą, nie była to fabryka, lecz dobrze prosperujący warsztat. Firma oferowała przybory samochodowe, dorabianie części, remonty i lakierowanie samochodów, remonty maszyn rolniczych, sprzedaż benzyny, opon, jak również usługi spawalnicze, frezarskie i wul-

9 „Słowo Pomorskie” [dalej: Sł. Pom.] 1921.01.28, R. 1, nr 21, s. 5; Sł. Pom. 1921.02.04, R. 1, nr 26, s. 5; Sł. Pom. 1921.02.09, R. 1, nr 30, s. 6.

${ }^{10}$ K. Kluczwajd, Toruń między wojnami. Opowieść o życiu miasta 1920-1939, Łódź 2011, s. 52.

${ }^{11}$ Por.: K. Przybyszewski, Toruń w Drugiej Rzeczypospolitej 1920-1939. Spoteczeństwo i gospodarka, Toruń 1994, s. 93.

12 Sł. Pom. 1921.05.20, R. 1, nr 112, s. 6; Sł. Pom. 1921.05.22, R. 1, nr 114, s. 9; Sł. Pom. 1921.05.24, R. 1, nr 115, s. 5; Sł. Pom. 1921.05.29, R. 1, nr 119, s. 11.

13 Sł. Pom. 1922.01.06, R. 2, nr 5, s. 6. Błędne są ustalenia Mieczysława Wojciechowskiego, Kazimierza Przybyszewskiego oraz Ryszarda Sudzińskiego, którzy podają, że Pomorska Fabryka Samochodów, Motorów i Maszyn Bracia Cierpiałkowscy powstała w 1920 r., zob.: M. Wojciechowski, W czasach Drugiej Rzeczypospolitej (1920 -1939), [w:] Toruń dawny i dzisiejszy. Zarys dziejów, red. M. Biskup, Warszawa-Poznań-Toruń 1983, s. 432; K. Przybyszewski, op. cit., s. 93; R. Sudziński, Życie gospodarcze, [w:] Historia Torunia, red. M. Biskupa, t. 3, cz. 2: W czasach Polski Odrodzonej i okupacji niemieckiej (1920-1945), Toruń 2006, s. 89. Firma do roku 1922 funkcjonowała pod nazwą Auto-Centrala Bracia Cierpiałkowscy. Formalna rejestracja siedziby firmy przy Szosie Chełmińskiej 33 musiała mieć miejsce w okresie od 1 do 31 sierpnia 1924 r., zob.: Zmiany w handlu i przemyśle, „Tygodnik Toruński” [dalej: Tyg. Tor.] 1924.09.06, R. 1, nr 36, s. 4. 
kanizacyjne ${ }^{14}$. Bracia oferowali też przebudowę samochodów i motorów starszej konstrukcji, sprzedaż i kupno samochodów, motorów i maszyn oraz przyjmowanie pojazdów w komis ${ }^{15}$. Pod adresem Szosa Chełmińska 33, gdzie mieściła się nowa siedziba firmy, mieszkał wraz z rodziną jeden z braci - Konstanty. Paweł zaś zameldowany był pięć numerów dalej - przy Szosie Chełmińskiej $38^{16}$.

Pod koniec 1922 r. Bracia Cierpiałkowscy posiadali 14 samochodów (3 osobowe i 11 ciężarowych $)^{17}$, głównie produkcji niemieckiej ${ }^{18}$. Na podstawie deklaracji o posiadanym taborze, składanych przez właścicieli pojazdów do Magistratu ${ }^{19}$, dowiadujemy się, że 11 samochodów należących do braci Cierpiałkowskich zupełnie nie nadawało się do jazdy i większość pochodziła z demobilu. Zostały zakupione od Oddziału Likwidacji Demobilu Wojskowego DEMAT jako tzw. szmelc. Jeden samochód osobowy Benz z 1912 r., który wymagał kapitalnego remontu, Cierpiałkowscy kupili od Starostwa Powiatowego w Toruniu, a sprawny Gräf i Stift z 1912 r. przeznaczyli na potrzeby szkoły szoferskiej ${ }^{20}$.

$\mathrm{Z}$ jednej strony ograniczona podaż nowych samochodów na początku lat 20., z drugiej brak dostępu do większego kapitału, skazywały Cierpiałkowskich na pozyskiwanie uszkodzonych pojazdów z demobilu. Paradoksalnie było to przyczyną dynamicznego rozwoju ich zakładu.

Wkrótce, spośród przeznaczonych na sprzedaż używanych samochodów, firma oferowała pojazdy osobowe i ciężarowe uznanych marek:

${ }^{14}$ Księga adresowa miasta Torunia wraz z Podgórzem i powiatem Toruń-wieś, Toruń 1923, dział ogłoszeń, Sł. Pom. 1922.01.06, R. 2, nr 5, s. 6.

15 Sł. Pom. 1922.01.06, R. 2, nr 5, s. 6.

16 Ksiega adresowa..., Toruń 1923, s. 162.

17 Zob. tabela (załącznik do artykułu).

18 Archiwum Państwowe w Toruniu [dalej: APT], Akta miasta Torunia 1920-1939 [dalej: AmT D], sygn. 417, k. 16-18, 25-35.

19 Podstawę prawną obowiązku składania deklaracji stanowiło Rozporządzenie Ministra Spraw Wewnętrznych z dn. 18.08.1922 r. Nr A.W.1521, Rozporządzenie Wykonawcze Ministra Spraw Wojskowych z dn. 11.05.1922 r. do ustawy o obowiązku odstępowania zwierząt pociągowych i wozów na rzecz Państwa (Dz.U. nr 36, poz. 310) oraz Zarządzenie Wojewody Pomorskiego z dn. 09.10.1922 r. dotyczące spisu taboru samochodowego.

${ }^{20}$ APT, AmT, D 417, k. 16-18, 25-35. 
Stoewer ${ }^{21}$, Gräf i Stiff ${ }^{22}$, Daimler ${ }^{23}$, Berliet ${ }^{24}$, Benz $^{25}$, Hansa Loyd ${ }^{26}$, Ope ${ }^{27}$, Ford $^{28}$, Wanderer ${ }^{29}$, Fulmina ${ }^{30}$ oraz motocykle Alba ${ }^{31}$ i Indian. Mając dostęp do używanych, często niesprawnych samochodów, odkupywali je od dotychczasowych właścicieli po bardzo korzystnej cenie. Kupowane pojazdy niejednokrotnie rejestrowane były na małżonki braci Cierpiałkowskich - Annę i Walerię ${ }^{32}$. Bardzo często Cierpiałkowscy w transakcjach samochodowych byli tylko „szybkimi pośrednikami”. Wymowny w tym kontekście jest przykład związany z samochodem Władysława Ulatowskiego, toruńskiego autodorożkarza. Gdy wojewoda pomorski nakazał unieruchomić samochód o numerze rejestracyjnym P.M. 13168, będący własnością Władysława Ulatowskiego, ponieważ właściciel pomimo wezwania nie przedstawił pojazdu do powtórnego badania technicznego, policja nie była w stanie wykonać polecenia, gdyż Ulatowski dwa miesiące wcześniej sprzedał samochód firmie Bracia Cierpiałkowscy. Jak ustalił starszy posterun-

${ }^{21}$ Zob.: oferty zamieszczone w: Sł. Pom. 1922.04.28, R. 2, nr 98, s. 8; Sł. Pom. 1922.04.29, R. 2, nr 99, s. 8; Sł. Pom. 1922.04.30, R. 2, nr 100, s. 9; Sł. Pom. 1922.05.02, R. 2, nr 101, s. 8; Sł. Pom. 1922.05.06, R. 2, nr 104, s. 6; Sł. Pom. 1922.05.07, R. 2, nr 105, s. 11 .

${ }^{22}$ Zob.: Sł. Pom. 1922.11.19, R. 2, nr 266, s. 5; Sł. Pom. 1922.11.23, R. 2, nr 269, s. 6 .

${ }^{23}$ Zob.: Sł. Pom. 1922.12.10, R. 2, nr 284, s. 12; Sł. Pom. 1922.12.13, R. 2, nr 286, s. 6; Sł. Pom. 1922.12.15, R. 2, nr 288, s.7.

${ }^{24}$ Ibidem.

25 Zob.: Sł. Pom. 1923.01.10, R. 3, nr 6, s. 6; Sł. Pom. 1923.01.11, R. 3, nr 7, s. 8; Sł. Pom. 1923.01.12, R. 3, nr 8, s. 7; Sł. Pom. 1923.02.14, R. 3, nr 35, s. 8; Sł. Pom. 1923.02.16, R. 3, nr 37, s. 5; Sł. Pom. 1923.02.18, R. 3, nr 39, s. 16.

${ }^{26}$ Zob.; Sł. Pom. 1923.06.15, R. 3, nr 134, s. 8; Sł. Pom. 1925.05.17, R. 5, nr 115 , s. 15 .

27 Sł. Pom. 1923.12.08, R. 3, nr 282, s. 7; Sł. Pom. 1923.12.12, R. 3, nr 285, s. 6; Sł. Pom. 1923.12.14, R. 3, nr 287, s. 6.

${ }^{28}$ Zob.: Sł. Pom. 1925.01.10, R. 5, nr, 7, s. 7; Sł. Pom. 1925.01.13, R. 5, nr 9, s. 8; Sł. Pom. 1925.01.14, R. 5, nr 10, s. 9; Sł. Pom. 1925.03.28, R. 5, nr 73, s. 10; Sł. Pom. 1925.10.28, R. 5, nr 250, s. 10.

${ }^{29}$ Sł. Pom. 1925.05.17, R. 5, nr 115, s. 15.

30 Ibidem.

${ }^{31}$ Sł. Pom. 1923.09.27, R. 3, nr 221, s. 8.

32 APT, AmT, D 420, k. 197, 465. 
kowy, Cierpiałkowscy pojazdu również nie posiadali, bo nieco wcześniej sprzedali go inspektorowi szkolnemu w Brodnicy ${ }^{33}$.

Najlepszych transakcji bracia dokonywali w drodze licytacji. Tym sposobem Konstanty Cierpiałkowski nabył w Gdańsku samochód Brenabor D. Z. 5107, który przed dalszą odsprzedażą został wyremontowany w warsztatach firmy ${ }^{34}$.

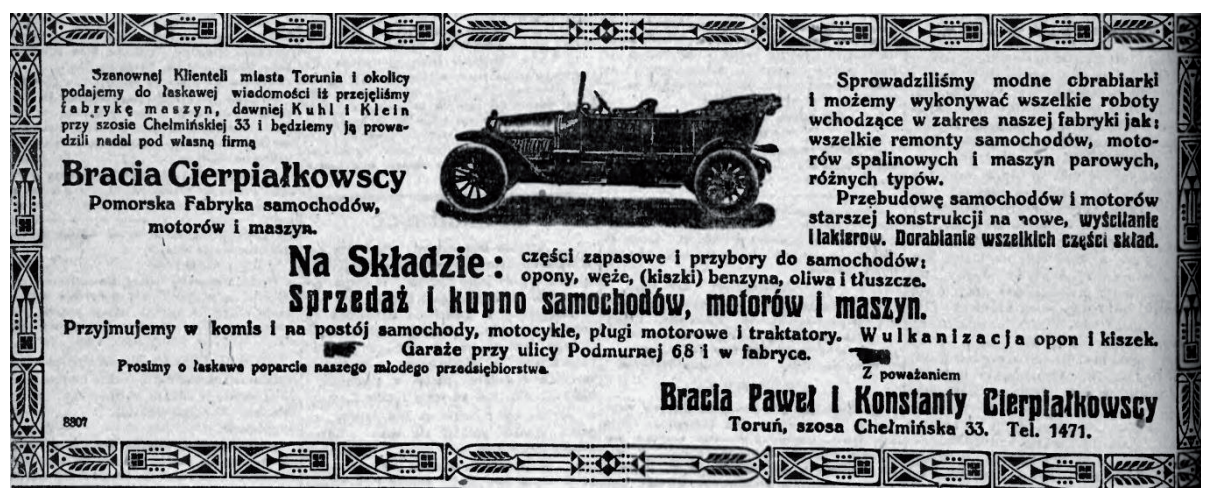

Przykładowa reklama prasowa Pomorskiej Fabryki Samochodów, Motorów i Maszyn Bracia Cierpiałkowscy.

Źródło: Sł. Pom. 1922.01.06, R. 2, nr 5, s. 6.

Jeszcze w 1922 r. do wyposażnia warsztatów zakupiono urządzenia z zagranicznych fabryk ${ }^{35}$. Pomimo przeniesienia siedziby firmy na Szosę Chełmińską $33^{36}$, gdzie mieściły się hale po byłej fabryce „Kuhl i Klein”, nieruchomości przy ul. Podmurnej 6/8 nie zostały sprzedane. Pod dawnym adresem bracia prowadzili usługi garażowania samochodów, co przy skromnej ofercie tego typu w obrębie Starego Miasta mogło cieszyć się zainteresowaniem nielicznych właścicieli samochodów.

${ }^{33}$ APT, AmT, D 416, [brak paginacji].

${ }^{34}$ Ibidem.

35 Sł. Pom. 1922.05.14, R. 2, nr 111, s. 10; Sł. Pom. 1922.05.18, R. 2, nr 114, s. 6; Sł. Pom. 1922.05.21, R. 2, nr 117, s. 8.

36 Skład firmy mieścił się również przy ul. Grudziądzkiej, zob.: Księga adresowa..., Toruń 1923, dział IV, s. 16. 
W 1923 r. firma została przedstawicielem na całą Polskę niemieckiej spółki akcyjnej Schlee-Werk, produkującej świece, filtry i inne części samochodowe. Elementy odlewnicze jak tłoki, zawory i panewki firma produkowała samodzielnie ${ }^{37}$, specjalizując się w stalowych trybach własnej produkcji ${ }^{38}$.

Ponadto Cierpiałkowscy prowadzili przedstawicielstwo producenta opon Bergougnan, szeroko promując jego produkty w lokalnej prasie ${ }^{39}$. Warto wskazać, że właśnie w obszarze reklamy firma potrafiła skutecznie odwoływać się do zabiegów socjotechnicznych, bazujących na emocjach potencjalnych klientów. Tekst reklamowy: „Wszak co wczoraj wydawało się zbytkiem, dziś okazuje się potrzebą. Nie sprzeczajmy się, gdyż każdy z nas potrzebuje samochód, motocykl i rower" ${ }^{20}$, uznać można za skuteczną próbę wykazania potrzeby konsumentowi. Do tego doskonale wykorzystywano gospodarcze nastroje patriotyczne: „Nie potrzeba się już narażać na zwłokę i niewygodę sprowadzania części samochodowych z zagranicy, gdyż można takowe daleko wygodniej we własnym kraju i z własnej produkcji nabyć" 41 .

W okresie, w którym Cierpiałkowscy budowali toruńskie centrum motoryzacji, na światowych drogach królowały amerykańskie Fordy - samochody tanie i powszechnie dostępne. Nie dziwi zatem fakt, że dostępność tę postanowiła wykorzystać Pomorska Fabryka, sprowadzając do

37 Sł. Pom. 1923.04.17, R. 3, nr 87, s. 6; Sł. Pom. 1923.04.22, R. 3, nr 92, s. 8; Sł. Pom. 1923.05.06, R. 3, nr 103, s. 9.

38 Sł. Pom. 1925.04.12, R. 5, nr 86, s. 12; Sł. Pom. 1925.04.19, R. 5, nr 91, s. 14; Sł. Pom. 1925.05.10, R. 5, nr 109, s. 12.

39 Zob.: Sł. Pom. 1923.04.19, R. 3, nr 89, s. 7; Sł. Pom. 1923.04.26, R. 3, nr 95, s. 7; Sł. Pom. 1923.04.27, R. 3, nr 96, s. 7; Sł. Pom. 1923.05.03, R. 3, nr 101, s. 9; Sł. Pom. 1923.05.10, R. 3, nr 106, s. 8; Sł. Pom. 1923.05.13, R. 3, nr 108, s. 11; Sł. Pom. 1923.05.17, R. 3, nr 111, s. 8; Sł. Pom. 1923.05.24, R. 3, nr 116, s. 7; Sł. Pom. 1923.05.29, R. 3, nr 120, s. 7; Sł. Pom. 1923.05.31, R. 3, nr 122, s. 7; Sł. Pom. 1923.06.07, R. 3, nr 127, s. 6; Sł. Pom. 1923.06.12, R. 3, nr 131, s. 7; Sł. Pom. 1923.06.13, R. 3, nr 132, s. 9; Sł. Pom. 1923.06.14, R. 3, nr 133, s. 5; Sł. Pom. 1923.06.16, R. 3, nr 135, s. 7; Sł. Pom. 1923.07.04, R. 3, nr 149, s. 7; Sł. Pom. 1923.07.19, R. 3, nr 162, s. 7; Sł. Pom. 1923.07.26, R. 3, nr 168, s. 6.

${ }^{40}$ Sł. Pom. 1924.07.25, R. 4, nr, 171, s. 9.

${ }^{41}$ Ibidem. 
Torunia osobowe Fordy z otwartym nadwoziem. Do swojego składu bracia zamawiali zwykle większe partie samochodów, do których jesienią oferowali „nadbudówki”, czyli dachy umożliwiające przykrycie nadwozia otwartego typu kabriolet ${ }^{42}$. W 1926 r. firma uruchomiła Ford Service Station - autoryzowaną przez Ford Motor Company stację naprawy pojazdów tej marki ${ }^{43}$.

Połowa lat 20. była najlepszym okresem w rozwoju przedsiębiorstwa. Szacuje się, że zatrudnienie w nim znalazło od 20 do 50 osób ${ }^{44}$. Pojawiły się nawet pomysły zorganizowania przyzakładowego hotelu pracownicznego lub domów dla pracowników na gruncie należącym do firmy ${ }^{45}$, lecz ostatecznie projektu nie zrealizowano. W 1925 r. wyremontowano w warsztatach firmy ok. 150 samochodów, a wartość produkcji wynosiła od 200 do 250 tys. $\mathrm{zt}^{46}$.

Jeszcze na początku lat 20. bracia otworzyli szkołę szoferów, w której przygotowywali kursantów do egzaminu państwowego na uprawnienia szoferskie. Działalność szkoły bardzo wspomagała interes. Zgodnie z ówczesnymi przepisami kandydat na kierowcę, poza przygotowaniem teoretycznym i trzymiesięcznym kursem nauki jazdy, musiał odbyć sześciomiesięczną praktykę w wybranym warsztacie samochodowym w charakterze czeladnika ${ }^{47}$. Cierpiałkowscy uzyskiwali tym samym darmową siłę roboczą.

42 Sł. Pom. 1924.11.23, R. 4, nr 273, s. 15; Sł. Pom. 1924.11.25, R. 4, nr 274, s. 4; Sł. Pom. 1924.11.26, R. 4, nr 275, s. 8; Sł. Pom. 1924.11.30, R. 4, nr 279, s. 10; Sł. Pom. 1924.12.03, R. 4, nr 281, s. 8; Sł. Pom. 1924.12.06, R. 4, nr 284, s. 7; Sł. Pom. 1924.12.07, R. 4, nr 285, s. 14; Sł. Pom. 1924.12.10, R. 4, nr 286, s. 7; Sł. Pom. 1924.12.11, R. 4, nr 287, s. 9; Sł. Pom. 1924.12.12, R. 4, nr 288, s. 8; zob.: także reklamę „nadbudówki”: Sł. Pom. 1926.10.03, R. 6, nr 228, s. 13.

43 Sł. Pom. 1926.11.06, R. 6, nr 256, s. 11; Sł. Pom. 1926.11.18, R. 6, nr 266, s. 9.

${ }^{44}$ M. Wojciechowski, op. cit., s. 432; K. Przybyszewski, op. cit., s. 94; R. Sudziński, op. cit., s. 89. Kazimierz Przybyszewski podaje, że zatrudnienie na poziomie ok. 50 osób przypadło na rok 1925.

45 K. Kluczwajd, op. cit., s. 53.

${ }^{46}$ K. Przybyszewski, op. cit., s. 94.

47 Podstawę prawną w tym zakresie regulowało Rozporządzenie Ministra Robót Publicznych i Ministra Spraw Wewnętrznych z 6 lipca 1922 r. o ruchu samochodów i innych pojazdów mechanicznych na drogach publicznych; por.: M. Pyter, Prawne zasady użytkowania pojazdów mechanicznych w Drugiej Rzeczypospolitej, „Czasopismo Prawno- 
W szkole prawdopodobnie dochodziło do nadużyć. W listopadzie 1925 r. niechętny Cierpiałkowskim Klub Szoferów na Pomorzu doniósł, że wśród kursantów, którzy otrzymali świadectwo ukończenia kursu, są osoby, które w rzeczywistości do szkoły nie uczęszczały. Cierpiałkowscy mieli rzekomo wydać fałszywe świadectwa. Donos dotyczył również samego wykładowcy - inż. Dalbora - który zdaniem Klubu Szoferów nie prowadził wykładów teoretycznych, mimo że były one przewidziane w programie kursu. W sprawie wszczęto nawet dochodzenie karne, ale z powodu sprzecznych relacji świadków i braku dowodów postępowanie ostatecznie umorzono ${ }^{48}$.

W 1924 r. zaszła, niezwykle istotna dla dalszego funkcjonowania firmy, zmiana jej kierownictwa. Prawdopodobnie w sierpniu $1924 \mathrm{r}$. przedsiębiorstwo opuścił Paweł Cierpiałkowski ${ }^{49}$. Niespełna pół roku później Konstanty Cierpiałkowski reklamował się już jako jedyny właściciel Pomorskiej Fabryki Samochodów, Motorów i Maszyn Bracia Cierpiałkowscy ${ }^{50}$.

Pod kierownictwem Konstantego struktura organizacyjna firmy podzielona została na pięć działów, które oferowały szeroko zdywersyfikowane produkty i usługi w obszarze branży motoryzacyjnej. Należały do nich sprzedaż samochodów osobowych, ciężarowych, autobusów i motocykli (dział A); usługi napraw samochodów, traktorów, silników oraz produkcja części i akcesoriów (dział B); wulkanizacja, spajanie aluminium i innych metali (dział C); sprzedaż części i akcesoriów samochodowych, jak łożyska, opony, oliwa (dział D). Ostatni dział (dział E) obejmował usługi garażowania pojazdów, konserwację i wynajem samochodów, a także fachowe porady oraz szkołę szoferskąą

Historyczne” 2011, t. 63, z. 2, s. 100-101; zob. też: M. Hładij, Prawo automobilowe $w$ Drugiej Rzeczypospolitej w świetle podstawowych regulacji normatywnych, „Czasopismo Prawno-Historyczne” 2003, t. 63, z. 1, s. 85-98.

48 APT, AmT, D 416.

49 Sł. Pom. 1924.08.03, R. 4, nr 179, s. 12; S1. Pom. 1924.08.06, R. 4, nr 181, s. 7; Sł. Pom. 1924.08.08, R. 4, nr 183, s. 7; Sł. Pom. 1924.08.29, R. 4, nr 200, s. 8.

50 Zob.: Sł. Pom. 1925.03.01, R. 5, nr 50, s. 13; Sł. Pom. 1925.03.08, R. 5, nr 56, s. 14; Sł. Pom. 1925.03.22, R. 5, nr 68, s. 20; Sł. Pom. 1925.03.29, R. 5, nr 74, s. 20.

${ }^{51}$ Ibidem. 
Początkowo, po odejściu brata-wspólnika, nic nie zapowiadało nadejścia problemów. Przeciwnie, w kwietniu 1925 r. Pomorska Fabryka Samochodów, Motorów i Maszyn Bracia Cierpiałkowscy uzyskała wyłączne przedstawicielstwo na Pomorze w sprzedaży amerykańskich motocykli marki Indian Motocykle Company. Motocykle Indian, ze swym sztandarowym modelem Scout, uchodziły w latach 20. za najbardziej renomowane motory. W dniu 5 kwietnia 1925 r. w „Słowie Pomorskim” ukazało się oficjalne oświadczenie Generalnego Przedstawiciela na Europę PółnocnoWschodnią firmy Henryk Czaplicki Spółka z ogr. odp. w Gdańsku o powierzeniu firmie Bracia Cierpiałkowscy przedstawicielstwa sprzedaży motocykli Indian na Pomorze. Po tym fakcie Pomorska Fabryka natychmiast przeprowadziła kampanię reklamową w lokalnej prasie ${ }^{52}$.

W 1925 r. firmę opuścił jej dotychczasowy pracownik, Maksymilian Hartwig, który wkrótce otworzył własne przedsiębiorstwo „Centrala Samochodów i Akcesorii M. Hartwig i S-ka” przy ul. Łaziennej 21, która wyrosła na poważnego konkurenta ${ }^{53}$. Maksymilian Hartwig, pracując u Cierpiałkowskich jako kierownik wydziału handlowego ${ }^{54}$, nabył z pewnością umiejętności biznesowe i przygotowanie merytoryczne do prowadzenia własnego interesu.

Wcześniej w 1924 r., jak zostało wspomniane, firmę opuścit współwłaściciel Paweł Cierpiałkowski. Analiza materiału źródłowego dostarcza przesłanek, by sądzić, że to on był organizatorem interesu i jej pierwszym handlowcem. Gdy z firmy odszedł Maksymilian Hartwig, Konstanty Cierpiałkowski stracił dwie najważniejsze osoby, mogące przesądzić o powodzeniu przedsiębiorstwa. Sam, będąc kierownikiem technicznym i rzeczoznawcą samochodowym, Konstanty nie posiadał predyspozycji handlowca zdolnego do zwiększania przychodów ze sprzedaży. Do tego Paweł Cierpiałkowski i Maksymilian Hartwig podjęli wkrótce wzajemną współpracę.

52 Sł. Pom. 1925.04.05, R. 5, nr 80, s. 12; Sł. Pom. 1925.04.12, R. 5, nr 86, s. 12; Sł. Pom. 1925.04.19, R. 5, nr 91, s. 14; Sł. Pom. 1925.05.10, R. 5, nr 109, s. 12; Sł. Pom. 1925.06.28, R. 5, nr 148, s. 11; Sł. Pom. 1925.07.12, R. 5, nr 159, s. 11; Sł. Pom. 1925.07.19, R. 5, nr 165, s. 13.

${ }^{53}$ K. Kluczwajd, op. cit., s. 53.

${ }^{54}$ Sł. Pom. 1924.07.25, R. 4, nr, 171, s. 9. 
Pomimo roszad personalnych w kierownictwie, firma podejmowała nowe inicjatywy. W 1926 r. Pomorska Fabryka Samochodów, Motorów i Maszyn Bracia Cierpiałkowscy otrzymała zgodę na uruchomienie linii autobusowej łączącej Podgórz z Toruniem5 . Pod koniec czerwca 1926 r. do Magistratu w Podgórzu wpłynął, podpisany przez Konstantego Cierpiałkowskiego, wniosek Pomorskiej Fabryki o udzielenie zgody na uruchomienie autobusu na linii Podgórz Rynek-dworzec Toruń Miasto. Przewóz pasażerów miał zapewnić 40 osobowy autobus marki Renault na pełnych gumach ${ }^{56}$ - „Urządzenie wewnątrz wykwintne, zaś stan techniczny wozu gwarantuje, że autobus kursować będzie punktualnie stosując się do ustalonego rozkładu jazdy" ${ }^{57}$ - dodawał Konstanty Cierpiałkowski. Rozkład jazdy zaplanowano od godz. 7.00 aż do 21.00 z cogodzinną częstotliwością odjazdów ${ }^{58}$. Początkowo komunikację planowano rozpocząć od 1 lipca. Ponieważ pismo wojewody pomorskiego do Magistratu w Toruniu w sprawie udzielenia koncesji Pomorskiej Fabryce wpłynęło dopiero 23 lipca 1926 r., należy przypuszczać, że termin uruchomienia linii autobusowej opóźnił się.

W pierwszym kwartale 1927 r. w mieście zaczęły pojawiać się pogłoski o słabej kondycji firmy. Plotki musiały być na tyle dokuczliwe, że skłoniły do zabrania głosu zarządcę masy upadłościowej. Na łamach lokalnej prasy wydał on oświadczenie, w którym potwierdził ciąłość prowadzenia działalności przez Pomorską Fabrykę Samochodów, Motorów i Maszyn Bracia Cierpiałkowscy, lakonicznie dodając, że „wszelkie puszczane sprzecznie z powyższem pogłoski są nieprawdziwe" 59 . Mimo zapewnień w firmie nie działo się dobrze. W maju 1927 r. ukazało się ogłoszenie firmy o zamiarze sprzedania autobusu z możliwością rozłożenia zakupu na raty ${ }^{60}$. Zwiastowało to zakończenie działalności przewozowej, tym bardziej że od

55 APT, AmT, D 409; K. Kluczwajd, op. cit., s. 50.

${ }^{56}$ APT, AmT, D 409.

57 Ibidem.

58 Przykładowo bilet z Podgórza do dworca miejskiego kosztował 0,40 zł. Uczniowie i dzieci do 12 roku życia otrzymywali 50\% zniżkę, zob.: APT, AmT, D 409.

59 Sł. Pom. 1927.03.11, R. 7, nr 57, s. 8.

${ }^{60}$ Sł. Pom. 1927.05.19, R. 7, nr 114, s. 10; Sł. Pom. 1927.05.21, R. 7, nr 116, s. 10 . 
1927 r. za komunikację autobusową pomiędzy Toruniem a Podgórzem odpowiadały podgórskie firmy: Wincentego Lewandowskiego, Kazimierza Lewandowskiego oraz Marcina Serafina ${ }^{61}$.

W drugiej połowie lat 20. prowadzona przez Konstantego firma wyraźnie straciła na znaczeniu. Konstanty, który z wykształcenia był mechanikiem, skupił się na prowadzeniu kursów samochodowych ${ }^{62}$ oraz warsztatu, lokalizując działalność przy Woli Zamkowej 4/6. Swoich sił w motoryzacji spróbował również brat Walenty Cierpiałkowski, prowadzący warsztat samochodowy przy Szosie Chełmińskiej 33 ${ }^{63}$. Z uwagi na to, że był młodszy od Konstantego o 7 lat, a siedziba jego warsztatu mieściła się pod adresem Pomorskiej Fabryki, można przypuszczać, że w początkowym okresie działalności mógł otrzymać wsparcie od starszych braci.

Warto odnotować, że Cierpiałkowscy nie tylko potrafili prowadzić biznes, ale w swojej branży uchodzili za dobrych fachowców. Jeden z członków rodziny, Zygmunt, był nawet mechanikiem lotnictwa ${ }^{64}$ (ul. Bydgoska 86); Stanisław (ul. Bielańska 4/6) był kowalem ${ }^{65}$; Brunon kierownikiem tokarni (Wielkie Garbary 18); Paweł kowalem-ślusarzem (Szosa Chełmińska 136); a Piotr rzeźnikiem (Eazienna 20) ${ }^{66}$.

Jak z kolei potoczyły się losy drugiego z założycieli firmy Bracia Cierpiałkowscy? Paweł, w przeciwieństwie do brata, nie miał formalnego przygotowania technicznego, a z zawodu był kupcem. Zanim w 1926 r. otworzył własne przedsiębiorstwo Auto-Traktor, po opuszczeniu brata

${ }^{61}$ K. Ciesielska, T. Zakrzewski, 450 lat toruńskiego Podgórza (1555-2005), Toruń 2005, s. 74.

62 Przemysław Olstowski pisze, że Kursy Kierowców Samochodowych Konstanty Cierpiałkowski prowadził przy ul. Woli Zamkowej od 1925 r., zob.: P. Olstowski, Oswiata polska i niemiecka $w$ Toruniu $w$ latach 1920-1939, [w:] Historia Torunia, red. M. Biskup, t. 3, cz. 2, W czasach Polski Odrodzonej i okupacji niemieckiej (1920-1945), Toruń 2006, s. 359.

${ }^{63}$ Księga adresowa i informacyjna miasta Torunia, oprac. A. Krzyżanowski, Toruń 1932, s. 539-540, 545.

${ }^{64}$ Ibidem, s. 335.

${ }^{65}$ Ksiega adresowa przemystu, handlu i rzemiosta Zachodniej Polski (Wielkopolski, Pomorza, Ślaska i W. M. Gdańska), Poznań 1925, s. P 119; Księga adresowa miasta Torunia: wedtug stanu z czerwca 1936 r., oprac. M. Reinke, Toruń 1936, s. 126.

${ }_{66}$ Ksiega adresowa...1936 r., s. 125-126. 
w 1924 r. rozpoczął epizod współpracy z Maksymilianem Hartwigem, dotychczasowym kierownikiem wydziału handlowego w Pomorskiej Fabryce Samochodów.

W dniu 23 stycznia 1925 r. Paweł Cierpiałkowski wspólnie z Maksymilianem Hartwigem wystąpili z pismem do Magistratu z prośbą o wydanie zgody i wydzierżawienie placu na postawienie dwóch stacji benzynowych, których lokalizacje wnioskodawcy planowali: na Nowym Rynku w narożniku naprzeciw Apteki pod Lwem lub w narożniku naprzeciwko Gospody pod Modrym Fartuchem dla jednej stacji oraz na placu pomiędzy Bankiem Polskim a gazownią dla drugiej stacji. Stacje miały być czynne codziennie w godzinach od 7.00 do 24.00, a ich obsługą mieli zająć się inwalidzi wojenni ${ }^{67}$. Magistrat nie udzielił oficjalnej odpowiedzi wnioskodawcom, którzy o braku zgody na udzielenie koncesji dowiedzieli się osobiście w urzędzie budowlanym i natychmiast ponowili wniosek ${ }^{68}$. W odwołaniu od decyzji Magistratu dowiadujemy się, że przedsiębiorcy ponownie otrzymali odmowną odpowiedź bez podania przyczyn. Miasto sugerowało przy tym, aby starali się o miejsce dla stacji benzynowej przy Dworcu Miejskim lub przy Straży Pożarnej, co wnioskodawcy ujęli krótko: „stawianie takich stacji poza obrębem śródmieścia, nie odpowiada właściwemu celowi i byłoby na razie ryzykownym lokowania pieniędzy z kupieckiego punktu widzenia" ${ }^{69}$.

Wobec braku zgody Magistratu, Hartwig i Cierpiałkowski zwrócili się ponownie 23 lutego 1925 r. o udzielenie koncesji na postawienie stacji benzynowej, tym razem przy ul. Łaziennej $21^{70}$. Wniosek spotkał się z akceptacją Magistratu, który 2 marca wydał pozwolenie na budowę jednej stacji

67 APT, AmT, D 2764, k. 1-1v.

${ }^{68}$ Ibidem, k. 3-3v. Pismem z dnia 30 stycznia 1925 r. Cierpiałkowski i Hartwig odwołali się od decyzji Magistratu, argumentując, że ze względu na niewielką konstrukcję pompy paliwa zaproponowane narożniki ulic Nowego Rynku są właściwą lokalizacją. Ponadto nowoczesny system pompy nie zagraża bezpieczeństwu ruchu, co potwierdzają decyzje władz takich miast, jak Warszawa, Poznań, Bydgoszcz i Gdańsk, które zezwoliły na lokalizację stacji benzynowych w centrum.

69 APT, AmT, D 2764, k. 5.

70 Ibidem, k. 7. 
benzynowej przy ul. Łaziennej ${ }^{71}$. Kilka miesięcy później, w dniu 23 lipca 1925 r. Magistrat udzielił im kolejnej zgody na dzierżawę placu pod budowę drugiej stacji benzynowej na rogu ul. Odrodzenia i Szosy Chełmińskiej ${ }^{72}$. W tym czasie współpraca Pawła Cierpiałkowskiego z Maksymilianem Hartwigiem (Centrala Samochodów i Akcesorii M. Hartwig i S-ka) wyraźnie się zacieśniła. Jednak stacja benzynowa przy ul. Łaziennej 21 prowadzona przez Cierpiałkowskiego i Hartwiga nie funkcjonowała długo pod ich znakiem firmowym. W kwietniu 1926 r. została odkupiona przez firmę Karpaty Sprzedaż Produktów Naftowych Sp. z ogr. por. ${ }^{73}$. We wrześniu 1926 r. prezydent miasta Torunia podjął decyzję o cofnięciu nowemu nabywcy zezwolenia na stację benzynową przy ul. Łaziennej, uznając, że konsens na ustawienie tej stacji wystawiony został pod warunkiem każdorazowego odwołania na 2 lata dla firmy Hartwig i Cierpiałkowski, a ci stację sprzedali ${ }^{74}$. Po sprzedaży stacji, wspólnicy po raz kolejny zwrócili się do Magistratu (7 września 1926 r.) z prośbą o wydanie zgody na postawienie stacji benzynowej przed ich nowym lokalem znajdującym się w narożniku ul. Szerokiej i Mostowej celem scentralizowania interesu' ${ }^{75}$, na co jednak władze miasta nie wyraziły zgody. Stało się to powodem kolejnego odwołania, w którym przedsiębiorcy podnosili argument, że

ruch przy otwartej ulicy na narożniku Król. Jadwigi i Wielkich Garbar jest znacznie większy aniżeli na Mostowej - a mimo to udzielono tam koncesję na postawienie takiego aparatu. Jest faktem, że istnieje już jeden aparat przed hotelem pod Orłem na Mostowej, to jeszcze nie może być powodem monopolizowania ulicy przez jedne tylko przedsiębiorstwo tego rodzaju. Wolny handel w Wolnej Polsce przysługuje każdemu, kto swe obowiązki wobec Państwa wykonuje - a że nasza firma wywiązywała się ze swych obowiązków dotychczas należycie - o tem świadczą rekor i 11 pracowników, z których 5 utrzymuje swe ogniska domowe.

71 Zob. treść pozwolenia: APT, AmT, D 2764, k. 8.

${ }^{72}$ Ibidem, k. 17. Wydanie zgody Magistrat warunkował rocznym czynszem za dzierżawę placu w kwocie 250 zł.

73 Ibidem, k. 30-31.

${ }^{74}$ Ibidem, k. 45. Nowy właściciel, rafineria „Karpaty”, podjął działania w celu zmiany decyzji Magistratu, zob.: APT, AmT, D 2764. Ibidem k. 48-49, 56-57.

75 Ibidem, k. 35. 
Sądzimy, że nasza firma dała dosyć dowodów przez jej blisko dwuletnią działalność, że przez stworzenie w mieście pierwszej placówki samochodowej i postawienie na Pomorzu pierwszej stacji benzynowej systemu amerykańskiego, okazała dużo ruchliwości, przysparzając tym samym miastu korzyści ${ }^{76}$.

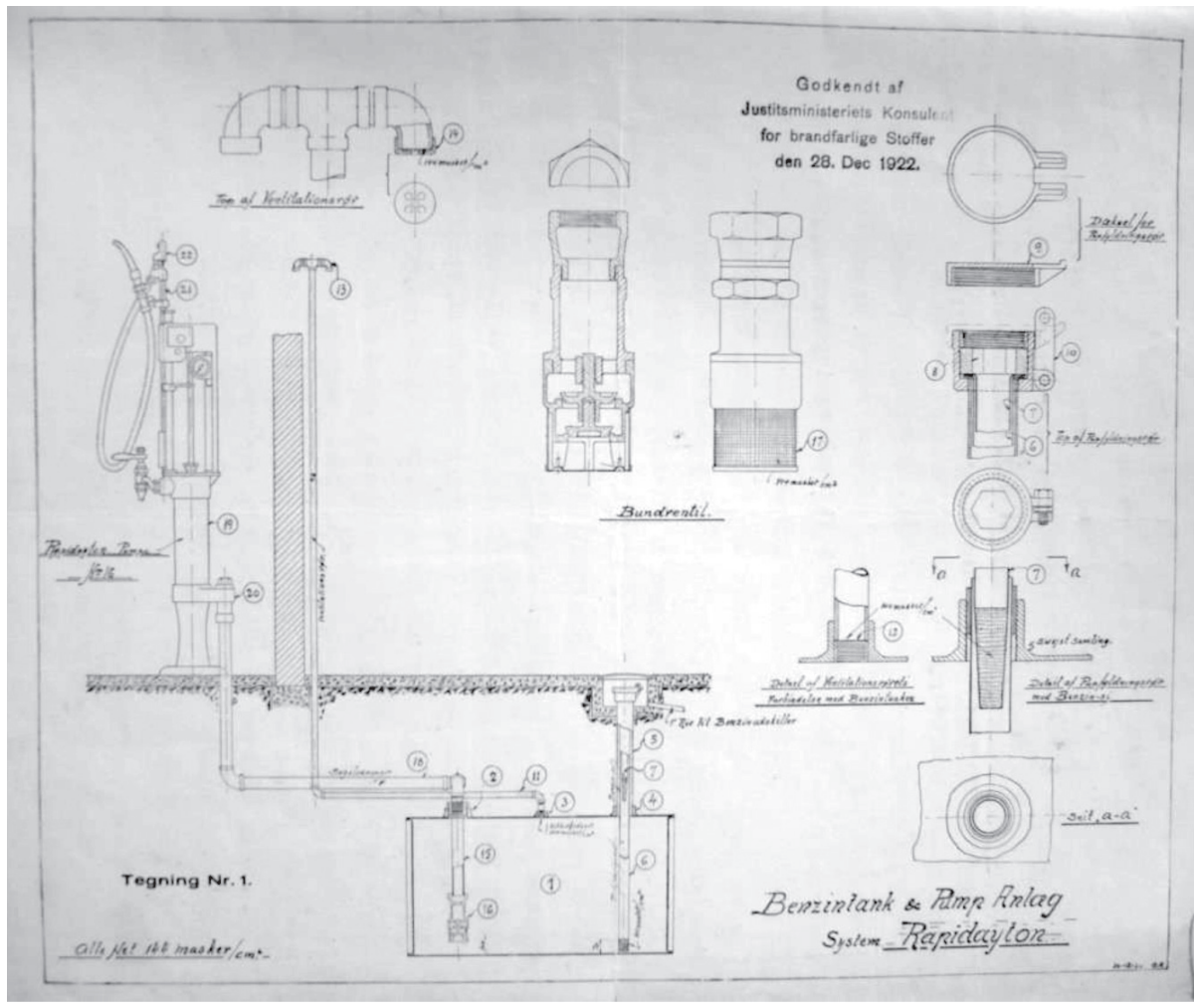

Schemat techniczny urządzeń do obsługi stacji benzynowej P. Cierpiałkowskiego i M. Hartwiga

Źródło: APT, AmT, D 2764, k. 2.

Jeszcze w sierpniu 1926 r., przed sporządzeniem odwołania od decyzji Magistratu, Paweł Cierpiałkowski zgłosił otwarcie swojego przedsiębiorstwa przy ul. Królowej Jadwigi 13/15, zajmującego się sprzedażą traktorów,

${ }^{76}$ Ibidem, k. 39. 
samochodów, artykułów technicznych, oliwy i benzyny ${ }^{77}$. Auto-Traktor tak nazywała się firma Pawła Cierpiałkowskiego - znajdowała się dokładnie w narożniku ulic Królowej Jadwigi i Wielkich Garbar (dzisiaj salon Empik). W swej ofercie posiadała samochody Fiat, Ford, traktory Fordson, opony Michelin i Firestone oraz inne akcesoria i części ${ }^{78}$. Obok Mercedesa, Benz, Paige i Studebaker, dominującą marką wśród oferowanych samochodów był oczywiście Ford. W maju 1927 r. Paweł Cierpiałkowski otrzymał autoryzację na prowadzenie przedstawicielstwa pojazdów Ford Motor Company. W reklamach można było nawet przeczytać, że Auto-Traktor jest jedynym legalnie autoryzowanym przedstawicielem Ford Motor Company na Toruń i całą Polskę $e^{79}$. Zainteresowanie Fordami było na tyle duże, że przy każdej nowej dostawie organizowano specjalne wystawy dla potencjalnych nabywców ${ }^{80}$.

W listopadzie 1926 r. Paweł Cierpiałkowski powrócił do budowy własnej stacji benzynowej. W poniedziałek 29 listopada 1926 r., podczas posiedzenia Wydziałów Administracyjnego i Finansów, Rada Miejska uchwaliła czynsz dzierżawny za plac wydzierżawiony firmie Auto-Traktor na postawienie stacji benzynowej ${ }^{81}$. Stacja benzynowa została zlokalizowana przy Szosie Chełmińskiej 3382, a więc pod adresem Pomorskiej Fabryki Samochodów, Motorów i Maszyn Bracia Cierpiałkowscy. Dziesięć lat później, w 1936 r., znajdowało się w Toruniu 10 stacji benzynowych, w tym jedna Cierpiałkowskiego. Była to forma dzierżawy (ajencji) pod szyldem spółki akcyjnej Standard-Nobel i nadal mieściła się przy Szosie Chełmińskiej, gdzie Paweł prowadził warsztaty i garaże ${ }^{83}$. W dniu 1 kwietnia 1927 r. Paweł Cierpiałkowski zgłosił ich otwarcie przy Szosie

77 Tyg. Tor., nr 37 (141), 11 września 1926, s. 10.

78 Sł. Pom. 1926.11.06, R. 6, nr 256, s. 10; Sł. Pom. 1926.11.16, R. 6, nr 264, s. 9; zob. ofertę handlową opon Firestone: Sł. Pom. 1928.06.19, R. 8, nr 139, s. 9; Sł. Pom. 1928.07.15, R. 8, nr 161, s. 11; Sł. Pom. 1928.07.22, R. 8, nr 167, s. 3.

79 Sł. Pom. 1927.05.18, R. 7, nr 113, s. 11; Sł. Pom. 1927.06.19, R. 7, nr 138, s. 12 .

${ }^{80}$ St. Pom. 1928.02.11, R. 8, nr 34, s. 7.

${ }^{81}$ Tyg. Tor., nr 48 (152), 27 listopada 1926, s. 2.

${ }^{82}$ Księga adresowa..., Toruń 1932, s. 518, 539.

${ }^{83}$ Książka adresowa... 1936 r., s. 51. 
Chełmińskiej 33, jako fabryki motorów i maszyn. W chwili uruchomienia warsztatów firma zatrudniała 12 osób $^{84}$. Po niespełna dwóch miesiącach urzędowania w warsztatach przy Szosie Chełmińskiej 33 Paweł wykupił świadectwo przemysłowe na prowadzenie tokarni i montowni ${ }^{85}$.

Firma Auto-Traktor, tak jak Pomorska Fabryka Samochodów, prowadziła kursy samochodowe. Były to kursy jazdy dla pań i panów, zarówno zawodowe, jak i amatorskie ${ }^{86}$. Szkolenia prowadzone były w sali wykładowej oraz w warsztatach przy Szosie Chełmińskiej 33, zapisy przyjmowano zaś w biurze przy Królowej Jadwigi 13/15 (tel. 1471, 400). Co ciekawe, w świadomości potocznej mieszkańców Torunia marka „Bracia Cierpiałkowscy” musiała być mocno utrwalona, skoro Paweł Cierpiałkowski wykorzystywał jej nazwę w reklamach poświęconych kursom samochodowym. Umieszczał ją w nagłówku, a oficjalną nazwę firmy Auto-Traktor podawał małą czcionką u dołu reklamy ${ }^{87}$.

Ponadto Paweł Cierpiałkowski przy Chełmińskiej nadal prowadził garaże samochodowe, a przy Królowej Jadwigi 13/15 otworzył sklep z bielizną. Po czterech latach działalności, w 1930 r. przeniósł siedzibę AutoTraktor z Królowej Jadwigi 13/15 na ulicę Chełmińską 9 ${ }^{88}$, gdzie obniżono okno wystawowe i przebudowano ściankę działową w celu dostosowania obiektu do nowych potrzeb ${ }^{89}$. Jeszcze w listopadzie 1930 r. w prasie ukazała się, skierowana do klientów firmy, informacja o przeniesieniu siedziby firmy na Chełmińską $9^{90}$. Od 1932 r. biuro i skład firmy mieściły się przy ul. Chełmińskiej 11 (tel. 400), a warsztaty i garaże przy Chełmińskiej 37 $\left(\right.$ nr tel. 1471) ${ }^{91}$.

${ }^{84}$ APT, AmT, D 1000, k. 10.

85 Ibidem, k. 6.

${ }^{86}$ K. Kluczwajd, op. cit., s. 53.

87 Sł. Pom. 1930.09.07, R.10, nr 207, s. 10; Sł. Pom. 1930.09.11, R.10, nr 210, s. 7.

${ }^{88}$ K. Kluczwajd, op. cit., s. 53, 55.

89 Zob. wydane Pawłowi i Annie Cierpiałkowskim pozwolenia budowlane: Ogtoszenia Magistratu miasta Torunia, nr 45, 22 listopada 1930, s. 3, poz. 220; Ogtoszenia Magistratu miasta Torunia, R. 9, nr 1, 9 stycznia 1932, s. 4.

90 Zob. reklamę w: Sł. Pom. 1930.11.08, R.10, nr, 259, s. 9.

${ }^{91}$ Archiwum Państwowe w Bydgoszczy [dalej: APB], Urząd Wojewódzki Pomorski w Toruniu [dalej: UWP], sygn. 24761; Księga adresowa..., Toruń 1932, s. 539. W księdze 
Firma posiadała również krajowe przedstawicielstwo produkcji opon samochodowych marki Stomil i jak napisano w liście reklamowym do Dyrekcji Robót Publicznych w Toruniu:

jesteśmy w możności dostarczyć każdą ilość tychże opon po cenach ściśle fabrycznych. [...] Prosząc o łaskawe popieranie tej produkcji krajowej, pierwszej tego rodzaju w dziedzinie pneumatyków samochodowych i której wyroby w niczem nie ustępują konkurencji zagranicznej, kraślimy się $e^{92}$.

W latach 30. XX wieku tereny fabryczne przy Szosie Chełmińskiej obejmowały obszar $6070 \mathrm{~m}^{2}$ powierzchni, z czego $1800 \mathrm{~m}^{2}$ przypadało na budynki fabryczne. Moc zainstalowanych w nich silników elektrycznych wynosiła $17 \mathrm{KM}^{93}$, co przy ówczesnych warunkach gospodarczych plasowało firmę wśród średnich przedsiębiorstw Torunia.

W 1930 r. Paweł Cierpiałkowski podjął decyzję świadczącą o jego dojrzałości biznesowej. Dokonał przekształcenia formy prawnej własnego przedsiębiorstwa. Firma Auto-Traktor Paweł Cierpiałkowski zmieniła nazwę na Auto-Traktor Spółka z ograniczoną poręką (s. z o.p.) i stała się podmiotem prawa handlowego ${ }^{94}$. Spółka z ograniczoną poręką stanowiła odzwierciedlenie współczesnej spółki z ograniczoną odpowiedzialnością, której zasadniczą cechą jest ochrona majątku prywatnego właściciela (właścicieli) ${ }^{95}$. Właściciel spółki z o.o. odpowiada przed wierzycielami wyłącznie do wysokości kapitału zakładowego. Tym samym Paweł Cierpiałkowski

adresowej z 1932 r. w spisie przedsiębiorstw jako właściciel firmy Auto-Traktor widnieje Anna Cierpiałkowska.

${ }^{92}$ APB, UWP, sygn. 24761.

${ }^{93}$ K. Przybyszewski, op. cit., s. 93-94; R. Sudziński, op. cit., s. 88. Autorzy mieli na myśli garaże Pomorskiej Fabryki Samochodów, Motorów i Maszyn Bracia Cierpiałkowscy, podczas gdy chodzi o garaże należące do firmy Auto-Traktor.

${ }^{4}$ Sł. Pom. 1930.06.18, R.10, nr 139, s. 10; Sł. Pom. 1930.06.19, R.10, nr 140, s. 10 .

${ }^{55}$ Szerzej na temat spółek z ograniczoną poręką zob.: Zbiór Ustaw Ziem Zachodnich, t. 19, Kodeks handlowy obowiazujący na ziemiach zachodnich Rzeczypospolitej Polskiej oraz ustawa o spótkach z ograniczona poręka (przektad urzędowy z uwzględnieniem ustawodawstwa polskiego), Poznań 1924. 
mógł zaciągać zobowiązania i kredyty na rozwój firmy, chroniąc prywatny majątek w przypadku niepowodzenia przedsięwzięcia i jego ewentualnej windykacji. Należy przypuszczać, że ze względu na formalne procedury związane $\mathrm{z}$ napisaniem statutu i złożeniem wniosku rejestracyjnego w sądzie musiał korzystać z pomocy radcy prawnego, co również potwierdza skalę dojrzałości biznesowej.

W 1934 r. Paweł Cierpiałkowski był z pewnością zamożnym człowiekiem. W dniu 1 listopada napisał pismo do Zarządu Miejskiego, w którym stwierdził, że miasto nie posiada komunikacji autobusowej, której brak z punktu widzenia urbanistyki, wymogów estetycznych i bezpieczeństwa publicznego umieszcza Toruń na samym końcu spośród innych miast. Zaproponował więc, że wybuduje dworzec autobusowy na własny koszt według planu podlegającego zatwierdzeniu przez Zarząd Miejski. Wybudowanie dworca warunkowat jednak otrzymaniem zgody na uruchomienie przy dworcu stacji obsługi samochodowej wraz z bufetem ${ }^{96}$.

W 1936 r., jak podaje książka adresowa miasta Torunia, Paweł Cierpiałkowski był właścicielem trzech ściśle ze sobą powiązanych biznesów: „Auto-Traktor” przy ul. Chełmińskiej 11 (tel. 14-00), „Auto-Warsztaty” przy Szosie Chełmińskiej 37 (tel. 17-71) oraz stacji benzynowej pod handlową nazwą Standard-Nobel S.A. również przy Szosie Chełmińskiej $37^{97}$.

Brat Konstanty pozostał wierny mechanice, przeniósł tylko swoją działalność na ul. Strumykową 7/9. Warto dodać, że Konstanty Cierpiałkowski został również rzeczoznawcą sądowym orzekającym w zakresie wypadków samochodowych $^{98}$. We wspólnym interesie z bratem to on, jako kierownik wydziału technicznego Pomorskiej Fabryki Samochodów, Motorów i Maszyn ${ }^{99}$, odpowiadał za sferę techniczną, biznesowo pozostając w cieniu swojego brata. Świadczą o tym m.in. deklaracje z 1922 r. o posiadanym taborze samochodowym składane do Magistratu, na których za każdym razem podpisywał się wyłącznie Paweł, biorąc na siebie ciężar formal-

${ }^{96}$ APB, UWP, sygn. 24761. W źródłach archiwalnych nie odnajdujemy odpowiedzi na pismo Pawła Cierpiałkowskiego.

${ }_{97}$ Książka adresowa... 1936 r., s. 85.

${ }^{98}$ K. Kluczwajd, op. cit., s. 52.

99 Sł. Pom. 1924.07.25, R. 4, nr 171, s. 9. 
ny i organizatorski wspólnie prowadzonego interesu. Przede wszystkim świadczy o tym jednak wejście Pomorskiej Fabryki Samochodów w fazę schyłkową po odejściu brata i kierownika handlowego, a także zajęcie się, w końcowym rozrachunku, prowadzeniem drobnego warsztatu oraz kursów szoferskich.

O ile w spisie mieszkańców z 1908 r. odnotowany był tylko Antoni Cierpiałkowski zamieszkały na Podgórzu, o tyle w 1936 r. odnajdujemy 11 przedstawicieli rodziny Cierpiałkowskich zameldowanych w Toruniu. Karierę zrobiło tylko dwóch. Ich sposób działania zbliżony był do powszechnego modelu pionierów motoryzacji, zaczynających prace w niewielkim garażu. Sprzyjał im okres fascynacji automobilem oraz powojenne warunki gospodarcze, które charakteryzowały się niedoborem pojazdów mechanicznych. Zwróćmy również uwagę na fakt, że Cierpiałkowscy nie szukali protekcji w polityce. Żaden z braci ani krewnych nie był radnym, w przeciwieństwie do największego producenta rowerów w mieście Władysława Katafiasa. Kilkukrotne utarczki z Magistratem w zakresie udzielanych pozwoleń pokazują, że nie podejmowano też prób obejścia formalizmu urzędniczego.

Po rozdzieleniu formalnej współpracy, podczas gdy Konstanty prowadził stabilnie swój warsztat oraz kursy szoferskie, kariera Pawła rozwijała się dynamiczniej. Na tym etapie badań można jedynie przypuszczać, że kluczowe okazało się jego doświadczenie kupieckie. Otwarcie sklepu z bielizną jest doskonałym przykładem łatwości, z jaką potrafił zmieniać branże lub rozszerzać dotychczasowy profil działalności. Fakt, że pismo, które skierował w 1934 r. do Dyrekcji Robót Publicznych, pisał i datował na 1 listopada (Wszystkich Świętych) jest co najmniej wymowny. Podczas gdy większość mechaników w mieście, włącznie z jego bratem, skupiała się na technicznej stronie działalności, będąc rzetelnymi rzemieślnikami swojego fachu, Paweł Cierpiałkowski zajmował się organizacją i zarządzaniem przedsiębiorstwem oraz podejmowaniem działań mogących wygenerować nowe przychody.

Niestety z powodu braku źródeł nie jesteśmy w stanie poznać poziomu inteligencji finansowej właściciela Auto-Traktor. Z uwagi na generowanie sporych obrotów oraz funkcjonowanie przedsiębiorstwa jako samodzielnego podmiotu prawa handlowego firma musiała prowadzić pełną rachunkowość zdarzeń gospodarczych. Brak zachowanych w zbiorach archiwalnych 
sprawozdań finansowych ${ }^{100}$ pozbawia badacza możliwości przeanalizowania struktury bilansu, oszacowania poziomu zadłużenia czy wskaźników rentowności. Wiemy jedynie, że firma Pawła Cierpiałkowskiego, jak również Pomorska Fabryka Samochodów, Motorów i Maszyn Bracia Cierpiałkowscy uchylały się od składania do Głównego Urzędu Statystycznego sprawozdań dotyczących statystyki przemysłowej ${ }^{101}$. Można tylko dodać, że ignorowanie obowiązku sporządzania sprawozdań statystycznych na rzecz Głównego Urzędu Statystycznego było wówczas zjawiskiem nagminnym, charakterystycznym również dla znacznie większych przedsiębiorstw toruńskich ${ }^{102}$. Nie zmienia to jednak faktu, że w kwestii spełniania wymogów formalnych firma pozostawiała wiele do życzenia.

Podsumowując zmienne losy zawodowe braci Cierpiałkowskich, niedosyt pozostawia dla historyka brak odpowiedzi na wciąż otwarte pytanie: dlaczego Paweł opuścił brata i wraz z kierownikiem wydziału handlowego otworzyli konkurencyjne przedsiębiorstwa, z którymi rywalizacji Konstanty nie wytrzymał?

Tabela. Wykaz samochodów w posiadaniu braci Cierpiałkowskich w 1922 r.

\begin{tabular}{|c|c|c|c|c|c|c|}
\hline Lp. & $\begin{array}{c}\text { Rodzaj } \\
\text { samochodu }\end{array}$ & Marka & $\begin{array}{c}\text { Model, } \\
\text { seria, rok } \\
\text { produkcji }\end{array}$ & $\begin{array}{c}\text { Liczba } \\
\text { osób/ } \\
\text { /tadowność }\end{array}$ & $\begin{array}{c}\text { Moc } \\
\mathbf{w ~ K M}\end{array}$ & Inne \\
\hline 1 & osobowy & Berliet & $\mathrm{Nr} 6$ & 4 os. & $12 / 18$ & $\begin{array}{c}\text { Kupiony od Dematu } \\
\text { Wojskowego* } \\
\text { jako szmelc }\end{array}$ \\
\hline
\end{tabular}

${ }^{100}$ Zgodnie z ówczesnymi przepisami przedsiębiorstwo zatrudniające co najmniej 5 robotników zobowiązane było składać sprawozdania statystyczne dla Głównego Urzędu Statystycznego, zob.: APT, AmT, D 999. Niestety w źródłach brak sprawozdań firmy AutoTraktor oraz Pomorskiej Fabryki Samochodów, Motorów i Maszyn Bracia Cierpiałkowscy.

${ }_{101}$ Zob.: pisma Głównego Urzędu Statystycznego do Prezydenta miasta Torunia z dnia 23 XII 1927 r. oraz z 26 VI 1929 r. GUS zwracał się z prośbą, aby Magistrat wymierzył każdorazowo grzywny w kwocie 10 zł za niewysłanie sprawozdań dotyczących statystyki przemysłowej, zob.: APT, AmT, D 1000, k. 175, 413. Por.: nakaz karny z 3 VIII 1929 r. wraz z dowodem doręczenia, ibidem, k. 414, 415.

102 Por.: APT, AmT, D 1000, k. 433-461. 
Tabela - cd.

\begin{tabular}{|c|c|c|c|c|c|c|}
\hline Lp. & $\begin{array}{c}\text { Rodzaj } \\
\text { samochodu }\end{array}$ & Marka & $\begin{array}{c}\text { Model, } \\
\text { seria, rok } \\
\text { produkcji }\end{array}$ & $\begin{array}{c}\text { Liczba } \\
\text { osób/ } \\
\text { /ładowność }\end{array}$ & $\begin{array}{c}\text { Moc } \\
\text { w KM }\end{array}$ & Inne \\
\hline 2 & osobowy & Benz & 1912 & 6 os. & $10 / 30$ & $\begin{array}{c}\text { Kupiony } \\
\text { od Starostwa } \\
\text { Powiatowego } \\
\text { w Toruniu; przezna- } \\
\text { czony do remontu } \\
\text { i odsprzedaży }\end{array}$ \\
\hline 3 & osobowy & $\begin{array}{l}\text { Gräf } \\
\text { i Stift }\end{array}$ & 1912 & 6 os. & $18 / 45$ & $\begin{array}{l}\text { Przeznaczony dla } \\
\text { szkoły szoferskiej }\end{array}$ \\
\hline 4 & ciężarowy & Adler & 1905 & $1 \mathrm{t}$ & 8,3 & $\begin{array}{l}\text { Przeznaczony do } \\
\text { rozbiórki; wcześniej } \\
\text { przerobiony } \\
\text { z osobowego }\end{array}$ \\
\hline 5 & ciężarowy & Ehrhardt & 1914 & $3 t$ & $21-30$ & $\begin{array}{l}\text { Kupiony od Dematu } \\
\text { Wojskowego, niena- } \\
\text { dający się do użytku }\end{array}$ \\
\hline 6 & ciężarowy & $\begin{array}{l}\text { Hansa } \\
\text { Loyd }\end{array}$ & 1913 & $4 \mathrm{t}$ & 35 & $\begin{array}{l}\text { Kupiony od Dematu } \\
\text { Wojskowego } \\
\text { jako szmelc }\end{array}$ \\
\hline 7 & ciężarowy & Belsys & - & $4 \mathrm{t}$ & 45 & $\begin{array}{c}\text { Kupiony od Dematu } \\
\text { Wojskowego } \\
\text { jako szmelc }\end{array}$ \\
\hline 8 & ciężarowy & $\begin{array}{c}\text { Hansa } \\
\text { Loyd }\end{array}$ & 1913 & $4 \mathrm{t}$ & 35 & $\begin{array}{c}\text { Kupiony od Dematu } \\
\text { Wojskowego } \\
\text { jako szmelc }\end{array}$ \\
\hline 9 & ciężarowy & Daimler & 1914 & $4 \mathrm{t}$ & 35 & $\begin{array}{l}\text { Kupiony od Dematu } \\
\text { Wojskowego } \\
\text { jako szmelc }\end{array}$ \\
\hline 10 & ciężarowy & Daimler & 1914 & $4,5 \mathrm{t}$ & 35 & $\begin{array}{l}\text { Kupiony od Dematu } \\
\text { Wojskowego } \\
\text { jako szmelc }\end{array}$ \\
\hline
\end{tabular}


Tabela - cd.

\begin{tabular}{|c|c|c|c|c|c|c|}
\hline Lp. & $\begin{array}{c}\text { Rodzaj } \\
\text { samochodu }\end{array}$ & Marka & $\begin{array}{c}\text { Model, } \\
\text { seria, rok } \\
\text { produkcji }\end{array}$ & $\begin{array}{c}\text { Liczba } \\
\text { osób/ } \\
\text { /tadownośćc }\end{array}$ & $\begin{array}{c}\text { Moc } \\
\text { w KM }\end{array}$ & Inne \\
\hline 11 & ciężarowy & Daimler & 1914 & $4,5 \mathrm{t}$ & 35 & $\begin{array}{c}\text { Kupiony od Dematu } \\
\text { Wojskowego } \\
\text { jako szmelc }\end{array}$ \\
\hline 12 & ciężarowy & Daimler & 1914 & $4,5 \mathrm{t}$ & 35 & $\begin{array}{c}\text { Kupiony od Dematu } \\
\text { Wojskowego } \\
\text { jako szmelc }\end{array}$ \\
\hline 13 & ciężarowy & Daimler & 1914 & $4,5 \mathrm{t}$ & 35 & $\begin{array}{c}\text { Kupiony od Dematu } \\
\text { Wojskowego, niena- } \\
\text { dający się do użytku }\end{array}$ \\
\hline ciężarowy & Daimler & 1914 & $5 \mathrm{t}$ & 40 & $\begin{array}{c}\text { Kupiony od Dematu } \\
\text { Wojskowego } \\
\text { jako szmelc }\end{array}$ \\
\hline
\end{tabular}

* Oddział Likwidacji Demobilu Wojskowego DEMAT.

Źródło: APT, AmT, D 417, k. 16-18, 25-35.

\section{Career of the Cierpiatkowski Brothers, Owners of the Pomeranian Car, Motors And Machinery Factory (In The Interwar Torun)}

(SUMMARY)

The article discusses the professional lives of two brothers Paweł and Konstanty Cierpiałkowski who were the founders of the Pomeranian Car, Motors and Machinery Factory. The text focuses on the description of the course of careers of two brothers who started their business activity from repairing vehicles to the army of General Haller. At the beginning of the 20s Paweł and Konstanty founded the company which was engaged in the repair and sale of vehicles, which a few years later was transformed into a professional enterprise and employed nearly 50 people. After the acquisition of the former machine factory Kuhl and Klein the brothers Cierpiałkowski created by the road Chełmińska 33 in Torun the au- 
tomotive center offering a wide range of services, ranging from car repairs and machinery, the consignment of vehicles, the production of parts, accessories and fluid sales, after service garage and chauffeurs school. The text presents the structure of the company and the modification of the management after which the brothers stopped to work together and began their independent operations. The author tracks the parallel lives of Paweł and Konstanty, seeking a cause-and-effect relation of their different achievements. This article is a part of the trend called prosopography and tries to answer questions about the role of family relationships, relationships with the ruling elite, personality traits (entrepreneurial) and other determinants that decide about the success of the Cierpiałkowski family.

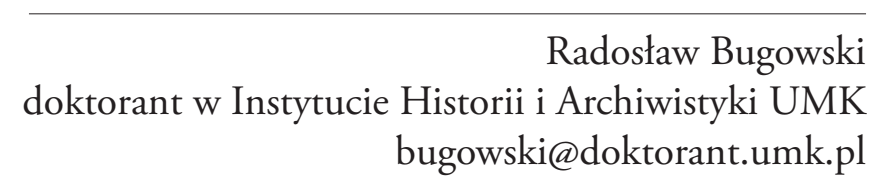

